\title{
FOREWORD
}

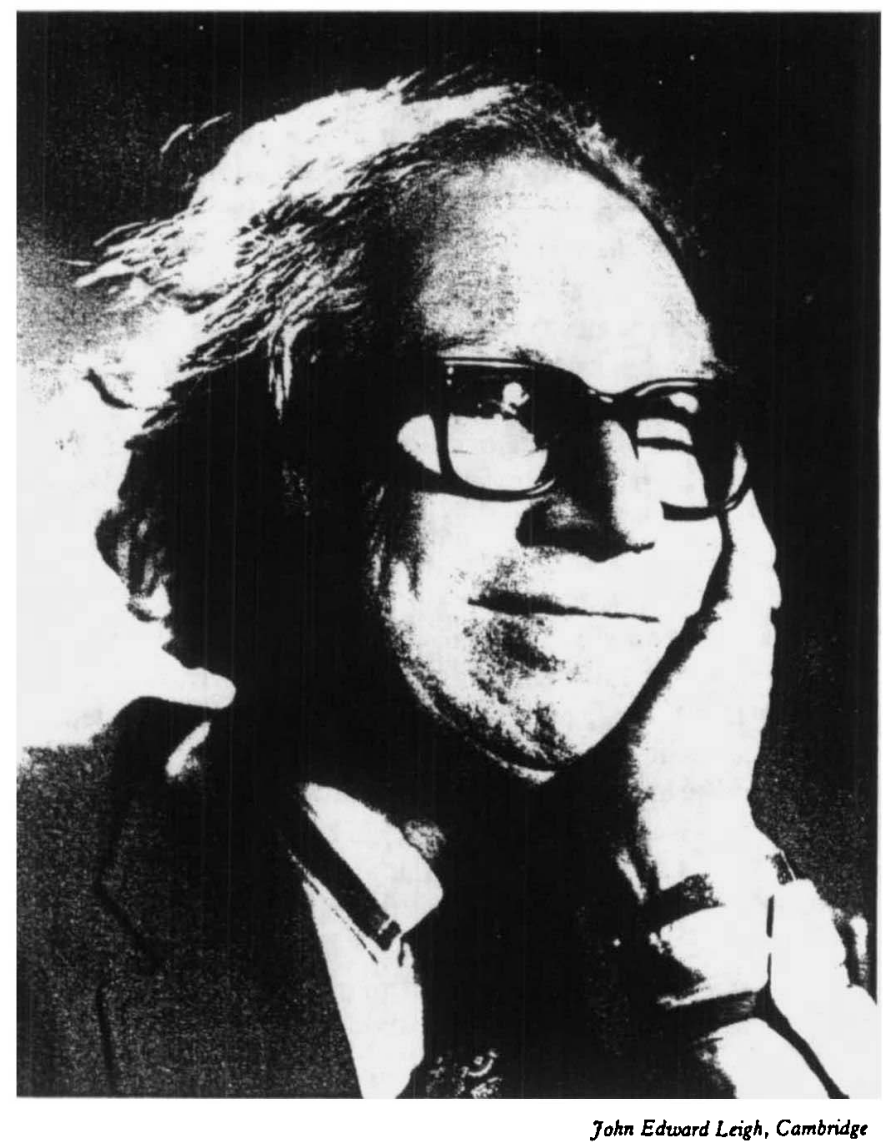

\section{HARRY KING}

Harry King will be taking early retirement on 31 December 1983, thus ending twenty-nine years as Librarian of the Scott Polar Research Institute. He should look back with satisfaction on his contribution to a period of remarkable growth of the Library and of the Institute.

The high reputation of the library, both within the University and internationally, was emphasized in the report of the General Board on the constitution of the Institute of 6 February 1980 (Polar Record 20 (126): 277-283). This has been due to the combined talents of two people-Harry King and, until 1978, the late Dr Brian Roberts. Although of different background and temperament, together they used their individual knowledge and abilities to develop an outstanding library. Brian Roberts provided the polar experience, the vision and the perfectionist's approach to the development of an outstanding polar library and information service. Harry King provided the skilled and understanding librarianship that, day in and day out, gradually built up the size, structure and organisation to their present efficient levels. His concern that a library is always there to serve the users, rather than to exist as a well-organised 
array of knowledge, has created a very effective working atmosphere in the library. Additionally, his genial presence and knowledgeable helpfulness are what many visitors to the Institute will best recall.

After serving as a radar mechanic in the Royal Air Force during World War II, Harry King completed a degree in History at University College, London in 1949. Following training with the Library Association he worked in the libraries of London University, the Institute of Historical Research and the Manchester Guardian before his appointment as Librarian of the Scott Polar Research Institute in January 1955. At that time there was one library assistant and a limited but valuable collection of books and manuscripts. The transformation since then is apparent to all who use the library. Highlights have been the opening of the new building in 1968 with its quadrupling of library space, the launching of Recent Polar Literature as a separate publication in 1973, and the publication of the library catalogue in nineteen volumes in 1976.

Harry King has taken a leading part in the development of international links and co-operation between polar libraries. His contacts with the growing circle of polar library specialists have increased through the Northern Libraries Colloquy. The series started in 1971, and Harry was chairman and organiser of their third colloquy held in the Institute in 1973. He has visited most of the polar libraries in the western world as a highly valued expert adviser.

In addition to organising polar knowledge as co-editor with Brian Roberts of the massive Library Catalogue already mentioned, and editing the five-volume supplement of 1979, Harry King has contributed to polar literature in other ways. His experience with the information service led to his popular and useful reference book, The Antarctic published in 1969. He edited Edward Wilson's Diary of the Terra Nova expedition (1972), and South Pole odyssey (1982) as well as organising fine reproductions of several of Wilson's Antarctic watercolours.

The level of excellence reached by the library and the exceptional achievements of its librarian were recognised in Harry King's promotion in 1975 to Under Librarian level in the university scale of posts, a rank conferred on very few departmental librarians. The warm, friendly, yet efficient atmosphere in the library constitutes the best record of his incumbency: we all thank him for his years of activity. 